\title{
PENINGKATAN EFEKTIVITAS PEMBELAJARAN MELALUI KOLABORASI PEMBELAJARAN KONVENSIONAL DAN PEMBELAJARAN VIRTUAL
}

\author{
Hastha Sunardi1), Dewi Sartika'2), Imelda Saluza ${ }^{3)}$ \\ 1)Program Studi Sistem Komputer, Universitas Indo Global Mandiri \\ 2)Program Studi Teknik Informatika, Universitas Indo Global Mandiri \\ 3)Program Studi Sistem Informasi, Universitas Indo Global Mandiri \\ Jalan Jend. Sudirman No. 629 KM. 4 Palembang Kode Pos 30129 \\ Email : $\underline{\text { hastha s@uigm.ac.id }}{ }^{1}$, dewi s@uigm.ac.id ${ }^{2}$, imelda@uigm.ac.id $^{3)}$
}

\begin{abstract}
ABSTRAK
Pembelajaran Berbasis Komputer adalah suatu bentuk model pembelajaran dengan memanfaatkan teknologi web dan internet. Berbagai istilah digunakan untuk mengemukakan gagasan tentang pembelajaran elektronik, antara lain adalah: on-line learning, internet-enabled learning, virtual learning, web based distance education, e-learning, web based teaching and learning. Selanjutnya penulis memilih pembelajaran elektronik dengan istilah pembelajaran virtual (virtual learning). Belum sepenuhnya penerapan pembelajaran virtual pada beberapa institusi pendidikan, khususnya pendidikan tinggi sebagaimana yang telah dicanangkan pemerintah sejak tahun 2013, maka penting untuk diperkenalkan penerapannya. Berbagai upaya terus dilakukan oleh para ahli, yang tentu saja agar diperoleh luaran yang lebih baik. Maka kini muncul pendekatan baru yang dinamakan Blended eLearning. Model ini merupakan gabungan keunggulan pembelajaran yang dilakukan secara tatap-muka dan secara virtual. Berangkat dari model ini, maka salah satu solusi alternatif agar proses pembelajaran sesuai yang diharapkan adalah dengan mengelaborasikan pembelajaran konvensional dan pembelajaran virtual, yaitu dengan tujuan jika terjadi hambatan dalam melaksanakan pembelajaran konvensional, maka pembelajaran virtual dapat dilakukan, sehingga tujuan pembelajaran tercapai. Hasil pengabdian, diantaranya memberikan pemahaman tentang pembelajaran virtual dan bagaiamana membangunnya, mampu memanfaatkan aplikasi yang dapat dimanfaatkan dalam proses pembelajaran, dan membuka mata pengajar akan penting teknologi informasi yang dapat diakses dengan mudah, baik dengan komputer maupun telpon genggam.
\end{abstract}

Kata kunci : e-learning, pembelajaran virtual, dialogis, edmodo, pembelajaran

\section{PENDAHULUAN}

Pembelajaran, merupakan kata penting yang menjadi bahasan dalam tulisan ini. Pembelajaran menurut pandangan konstruktivistik mengemukakan bahwa realitas ada pada pikiran seseorang. Manusia mengkonstruksi dan menginterpretasikannya berdasarkan pengalamannya. Konstruk-tivistik mengarahkan perhatian bagaimana seseorang mengkonstruksi pengetahuan dari pengalamannya, struktur mental dan keyakinan, dan keyakinan yang digunakan untuk menginterpretasikan objek dan peristiwa-peristiwa. Pandangan konstruktivistik mengakui bahwa pikiran adalah instrument penting dalam menginterpretasikan kejadian, objek, dan pandangan terhadap dunia nyata, dimana interpretasi tersebut terdiri dari pengetahuan dasar manusia (Budiningsih, 2005).

Konsep Pembelajaran Berbasis Komputer dan Jaringan adalah suatu bentuk model pembelajaran dengan memanfaatkan teknologi web dan internet, konsep belajar dan mengajar ini sebenarnya bukanlah barang baru, bukan juga ide ataupun pemikiran baru, bahkan sudah berkembang sejak beberapa dasawarsa lalu. Berbagai istilah digunakan untuk mengemukakan pendapat/gagasan tentang pembelajaran elektronik, antara lain adalah: on-line learning, internet-enabled learning, virtual learning, atau web-based learning, web based distance education, e-Learning, web based teaching and learning (Rabiah Adawi, 2008). Selanjutnya penulis memilih pembelajaran elektronik ( $e$ learning) dengan istilah pembelajaran virtual (virtual learning). Virtual Learning adalah salah satu sistem pendidikan jarak jauh yang bertujuan untuk mengefisiensikan dan mengefektifkan metode 
pembelajaran dengan menggunakan internet. Jarak dan waktu tidak lagi menjadi masalah dalam proses pembelajaran dalam Konsep Virtual Learning ini (Bibit Sih Handoko, 2017).

Belum sepenuhnya bahkan belum sama sekali penerapan/pengelolaan pembelajaran elektronik pada beberapa institusi pendidikan, khususnya pendidikan tinggi sebagaimana yang telah dicanangkan pemerintah sejak tahun 2013 (Permendikbud, 2013). Disisi lain, perkuliahan konvensional dengan jumlah tatap muka dalam satu semester untuk satu matakuliah sebanyak 16 kali pertemuan, tentunya pencapaian jumlah pertemuan tersebut bisa tidak terpenuhi, jika terjadi hambatan internal, seperti dosen yang berhalangan hadir karena tugas, sakit atau lainnya dan juga hambatan eksternal, seperti di musin hujan yang acap kali terjadi kebanjiran yang menyebabkan terjadinya kemacetan jalan, sehingga tidak sedikit perkuliahan gagal terlaksana. Model pembelajaran konvensional merupakan model pembelajaran yang berpusat pada pengajar dengan komunikasi satu arah melalui penyampaian informasi secara lisan kepada pembelajar. Model pembelajaran konvensional mengacu pada teori behavioristik, banyak didominasi oleh pengajar. Pengajar menyampaikan materi pembelajaran melalui ceramah, dengan harapan pembelajar dapat memahaminya dan memberikan respon sesuai dengan yang disampaikan. Materi yang disampaikan sesuai dengan urutan isi buku teks (Budiningsih, 2005).

Ada suatu model yang telah ditawarkan berupa upaya untuk mengatasi berbagai permasalahan penyelenggaraan pendidikan jarak jauh, antara lain: a. Meningkatkan kelemahan-kelemahan yang ada di bidang teknisnya atau infratsrukturnya. Misalnya meningkatkan kapasitas bandwith, perluasan Internet Service Provider (ISP), memperbanyak sambungan telepon, dan lain-lain. b. Mengatasi berbagai persoalan yang berkaitan dengan aspek finansial. seperti Misalnya dengan menyediakan biaya telepon murah, biaya langganan internet murah, harga komputer murah, dan lain-lain. c. Mengatasi berbagai persoalan yang berkaitan dengan aspek sosial. Misalnya menghilangkan keraguan masyarakat terhadap penyelengaraan pendidikan jarak jauh dengan cara memperbaiki sistem dan penyelenggaraan pendidikan jarak jauh, menyamakan lulusan pendidikan jarak jauh dengan lulusan lembaga pendidikan tatap muka, dan lain-lain. Pemikiran dan upaya untuk terus dilakukan oleh para ahli. Maksudnya tentu saja agar diperoleh keluaran (output) yang lebih baik. Maka kini muncul pendekatan baru yang dinamakan 'Blended e-Learning' (BEL). Model ini pada dasarnya mengkombinasikan keunggulan berbagai teknik pembelajaran dalam penyelenggaraan pendidikan jarak jauh. Karena itu, Blended e-Learning merupakan gabungan keunggulan pembelajaran yang dilakukan secara tatap-muka dan secara virtual (Syoekartawi, 2006).

Berangkat dari model diatas, maka salah satu solusi alternatif agar proses pembelajaran sesuai yang diharapkan adalah dengan mengelaborasikan pembelajaran konvensional dan pembelajaran virtual, yaitu jika terjadi hambatan dalam melaksanakan pembelajaran konvensional sebagaimana telah disebutkan sebelumnya, maka pembelajaran virtual dapat dilakukan, sehingga pencapaian pembelajaran berjalan sesuai sebagaimana tertuang pada Rencana Pembelajaran Semester (RPS).

\subsection{Target}

Kegiatan Pengabdian kepada Masyarakat ini bertujuan untuk membantu membangun suasana akademik kondusif dan responsif interaktif, guna menjadikan pengajar dan pembelajar lebih kreatif dan berkompetensi untuk memanfaatkan media pembelajaran virtual sebagai media pembelajaran sehingga kegiatan belajar mengajar (perkuliahan) dapat diimplementasikan jarak jauh dan memenuhi target pembelajaran sebagaimana mestinya.

\subsection{Luaran}

Hasil kegiatan Pelatihan Pelatihan Implementasi Perkuliahan Jarak Jauh dengan Media Pembelajaran Virtual antara lain:

1. Memberikan motivasi kepada pengajar dan pembelajar agar lebih memahami dan memanfaatkan teknologi informasi dan komnikasi untuk pendidikan.

2. Membantu pengajar dan pembelajar memahami konsep pembelajaran jarak jauh dan bagaimana mengimplementasikannya.

3. Membantu pengajar dan pembelajar dalam memahami dan memanfaatkan salah satu unsur media pembelajaran virtual, seperti edmodo. 
4. Mengaplikasikan media pembelajaran virtual yang telah dibuat untuk diterapkan dalam kegiatan perkuliahan jarak jauh.

\section{METODE PELAKSANAAN PENGABDIAN}

\subsection{Analisis dan Solusi Permasalahan}

Penerapan Penyelenggaraan Pendidikan Jarak Jauh pada Pendidikan Tinggi, sebagaimana tertuang pada Permendikbut No.109 Tahun 2013, hampir disebagian besar lembaga pendidikan tinggi, khususnya pendididkan tinggi yang di daerah belum menerapkannya. Hal ini bisa dipengaruhi faktor ketersediaan jaringan internet yang kapasitasnya belum memadai atau boleh jadi karena mempertimbangkan calon mahasiswanya yang belum dianggap mampu untuk mengenal dan mengikuti perkuliahan jarak jauh. Pembelajaran virtual, yang merupakan salah satu penyebutan pembelajaran jarak jauh, sebenarnya dapat diterapkan dalam proses pembelajaran jarak jauh dengan menerapkan atau memilih salah satu aplikasi, seperti moodle, edmodo atau lainnya.

Universitas IBA, salah universitas tertua di Palembang dengan lokasi di tengah Kota Palembang, telah lama memiliki Sistem Informasi Akademik on-line dengan jaringan infrastruktur yang memadai, sebenarnya dapat dengan mudah mengembangkan dan menerapkan sistem pembelajaran jarak jauh. Karenanya melalui kegiatan pengabdian pada masyarakat ini, tim pelaksana mencoba memberikan gambaran akan pentingnya penerapan sistem pembelajaran jarak jauh yang dalam hal ini pembelajaran virtual. Penerapan sistem pembelajaran jarak jauh tentunya tidak semudah yang diharapkan, namun tim menawarkan suatu proses pembelajaran yang mengkolaborasikan pembelajaran konvensional dan virtual, agar dapat saling melengkapi, dengan pencapaian agar proses pembelajaran tetap berjalan.

\subsection{Persiapan Pelaksanaan Pengabdian}

Pada tahapan persiapan, tim pelaksana cukup intensif melakukan koordinasi dengan panitia pelaksana dari pihak mitra, kemudian kami melakukan :

1. Diskusi dengan mitra tentang tempat pelaksanaan, jumlah peserta dan alokasi waktu pelatihan.

2. Menetapkan hari, tanggal kegiatan, tempat serta peralatan yang perlu dipersiapkan untuk pelaksanaan kegiatan pelatihan tersebut, persiapan yang dilakukan untuk pelaksanaan kegiatan tersebut adalah menyediakan ruang pelatihan beserta peralatan pendukung seperti laptop, proyektor dan lain-lain.

3. Mempersiapkan materi pelatihan dalam bentuk modul yang akan disampaikan kepada peserta.

4. Memastikan bahwa peserta pelatihan telah memiliki email atau setidaknya mampu mengikuti pelatihan pendahuluan bagaimana cara membuat email.

5. Menyepakati dan menetapkan waktu pelatihan, yakni pada hari Jum'at, tanggal 14 Desember 2018, Waktu 08.00-10.30 WIB, Tempat di Fakultas Ekonomi Universitas IBA Palembang, Sumatera Selatan.

\subsection{Pelaksanaan Pengabdian}

Pelaksanaan pengabdian dilakukan dalam bentuk pelatihan, diawali oleh tim pelaksana selaku nara sumber menyampaikan materi sesuai kesepakatan porsi masing-masing. Penyampaian materi oleh narasumber diawali tentang Konsep Pembelajaran Jarak Jauh, dasar hukum dan berbagai model yang dapat diterapkan oleh perguruan tinggi. Kemudian dilanjutkan penyampaian materi Implementasi Pembelajaran Jarak jauh. Tahapan ahir adalah penyampaian materi berupa praktek langsung membangun pembelajaran virtual, dengan menggunakan aplikasi edmodo. Pada tahapan ini, semua peserta diwajibkan membawa laptop atau telpon genggam agar dapat mengikuti dan mempraktekkan langsung bagaimana membangun dan melaksanakan serta mengikuti pembelajaran virtual. Peserta dosen difokuskan bagaimana mengelola edmodo untuk proses pembelajaran virtual, sedangkan mahasiswa difokuskan tentang bagaimana mengikuti jalannya pembelajran virtual, khususnya yang menyangkut mengikuti/mengakses materi juga menjawab tugas dan kuis. 
Tabel 1. Jadwal Pelaksanaan Kegiatan Pengabdian Kepada Masyarakat

\begin{tabular}{|c|c|c|}
\hline Pukul & Materi & Nara Sumber \\
\hline $08.00-08.30$ & Persiapan & Tim Pelaksana \\
\hline $08.30-09.00$ & Registrasi Peserta & Mahasiswa \\
\hline $09.00-09.30$ & Pembukaan\& Perkenalan & $\begin{array}{c}\text { Ketau Panitia Pelatihan FE } \\
\text { UIBA \& Tim Pelaksana }\end{array}$ \\
\hline $09.30-10.30$ & Penyampaian Materi/Praktek & $\begin{array}{c}\text { Hastha Sunardi / Imelda } \\
\text { Saluza / Dewi Sartika }\end{array}$ \\
\hline $10.30-$ selesai & Penutupan & Panitia Pelaksana FE UIBA \\
\hline
\end{tabular}

\section{HASIL DAN PEMBAHASAN}

\subsection{Hasil Pengabdian}

Berdasarkan penilaian selama jalannya pelatihan, respon peserta cukup tinggi yang ditunjukkan dengan intensifnya proses tanya jawab disaat pelatihan langsung membangun pembelajaran/kelas virtual, sehingga diperoleh hasil pengabdian :

1. Memberikan pemahaman tentang pembelajaran virtual dan bagaiamana membangunnya.

2. Mampu memanfaatkan aplikasi yang begitu dengan mudahnya diperoleh dihadapan kita, untuk kita manfaatkan dalam proses pembelajaran

3. Ketersediaan infrastruktur jaringan dengan kapasitas bandwidth yang memadai, memberikan nilai tambah bagi peserta, khususnya pengajar/dosen untuk segera mengimplementasikan hasil pelatihan

4. Membuka mata pengajar dan pembelajar untuk melek teknologi, khususnya teknologi informasi yang dapat diakses dengan mudah, baik dengan komputer maupun telpon genggam.

\subsection{Tindaklanjut yang Harus Dilakukan}

Kendala pelaksanaan program adalah dapat dikatan tidak ada sama sekali, karena pihak mitra cukup responsif bahkan tim pelaksana cukup puas dengan persiapan dan pelaksanaan pengabdian yang tertata cukup baik dan tertib. Hanya disaat sulitnya mengatur waktu untuk pencapaian kesepakatan pelaksanaan kegiatan, karena umumnya peserta latihan terbentur dengan rutinitas pekerjaan dan kegiatan lain, sehingga pelaksanaan pengabdian kepada masyarakatnya harus disesuaikan.

Sedangkan dari hasil pelaksanaan kegiatan pengabdian, didapatkan beberapa hal yang harus ditindaklanjuti pihak mitra diantaranya :

1. Perlu memotivasi para pengajar untuk memanfaatkan Sistem Informasi Akademik Universitas IBA, yang ternyata sudah memiliki fitur fasilitas pembelajaran online, namun perlu dikembangkan ke arah proses pembelajaran yang lebih interaktif.

2. Keterbatasan sarana kafasitas bandwidth sebenarnya tidak menjadi masalah untuk tingkat pemakaian sekarang, namun untuk pengembangan pembelajaran on-line atau pembelajaran virtual perlu diperbesar, seiring dengan peningkatan penggunaan internet utuk proses pembelajaran virtual.

3. Pemahaman pimpinan fakultas dan staf dosen tentang pembelajaran virtual cukup baik, namun perlu ditindaklanjuti pada tingkat rektorat.

\section{KESIMPULAN}

1. Peserta memiliki pemahaman tentang perbedaan model pembelajaran konvensional dan pembelajaran virtual

2. Peserta termotivasi untuk mengaplikasikan model pembelajaran virtual sebagai pelengkap pembelajaran konvensional 
3. Kegiatan ini dapat meningkatkan kemampuan para dosen di Fakultas Ekonomi Universitas IBA Palembang dalam pemanfaatan aplikasi pembelajaran, baik melalui PC/lapton maupun mobile/telpon genggam.

\section{UCAPAN TERIMA KASIH}

Tim pelaksana mengucapkan terima kasih kepada :

1. Rektor Universitas IGM, Bapak Dr. Marzuki Alie, SE.,MM.

2. Dekan Fakultas Ilmu Komputer, Ibu Lastri Widyastusi, M.Kom

3. Para Kaprodi di lingkungan Fasilkom Universitas IGM

4. Dekan Fakultas Ekonomi Universitas IBA, Ibu Endang Kusdianingsih, S.E., M.Si.

5. Para Kaprodi dan Dosen di lingkungan Universitas IBA

6. Para mahasiswa yang turut membantu Tim Pelaksana.

\section{DAFTAR PUSTAKA}

Budiningsih, A. C. 2005. Belajar dan pembelajaran. Jakarta: PT. Rieka Cipta.

Bibit Sih Handoko. 2017. Pemanfaatan teknologi informasi dan komunikasi untuk meningkatkan kualitas pembelajaran. http://guraru.org/guru-berbagi/virtual-learning-pemanfaatan-teknologiinformasi- dan-komunikasi-untuk-meningkatkan-kualitas-pembelajaran/, diunduh 22 Agustus 2019

Permendikbud. 2013. Penyelenggaraan Pendidikan Jarak Jauh pada Pendidikan Tinggi. https://jdih. kemdikbud.go.id/arsip/permen_tahun2013_nomor109.pdf, diunduh 13 Agustus 2019

Rabiah Adawi. 2008. Pembelajaran Berbasis E-Learning. http://digilib.unimed. ac.id/541/1/ Pembelajaran\%20Berbasis\%20E-Learning.pdf, diunduh 22 Agustus 2019

Soekartawi.2006. Blended/hybrid learning : Altematif Model Pembelajaran Jarak Jauh Di Indonesia (http://uny.ac.id) , diunduh 24 Agustus 2019 